\title{
Exploring the Relationship between Students' Perceptions of the Language Teacher and the Development of Foreign Language Learning Motivation
}

\author{
Morana Drakulić \\ Faculty of Teacher Education, University of Rijeka, Croatia
}

\begin{abstract}
The present study aims to examine the nature of the relationship between students' subjective perceptions of their foreign language teachers and language learning motivation. The participants were 592 Croatian elementary school learners who learn English as a foreign language as a compulsory subject. The findings of the current study reveal that the teacher's instructional competence was perceived as the most important characteristics, whereas the teacher's personality and his/her intercultural competence were perceived as less important. The results have also revealed that subjective interpretations of both competences related to the foreign language classroom instruction and personal characteristic affect students' motivation the most i.e. that the attitudes towards the learning situation may account for the variability in motivation. The present study findings draw on the importance of a quality language learning situation built on quality teacher-student relationship which, as such, facilitates both language learning motivation and the relative degree of success.
\end{abstract}

Index Terms-foreign language learning, students' subjective perceptions, effective language teacher characteristics, motivation

\section{INTRODUCTION}

In the last decades, the rise of English as lingua franca has affected the field of foreign language education in terms of the redefinition of the existing learning outcomes and, consequently, the entire teaching and learning process. In this connection, much attention has been dedicated to the investigation of the 'ideal' language learning environment, i.e. the myriad of factors that affect the quality and successfulness of foreign language learning in the formal context.

The issue of, what is in the literature often called, powerful learning environments has so far been addressed from many different perspectives. At the global level, efforts have been directed towards the development of sustainable policies which would ensure the quality of provision for children learning foreign languages (Enever, 2011 p. 38). The extensive empirical research in the field of applied linguistics has also tackled a variety of issues, ranging from the teaching methodology and learner characteristics to a wide range of contextual factors which may affect the quality of the learning as a whole. However, as Horwitz (2000) points out, 'all discussions of the goals of language teaching, the benefits of language learning (...) and appropriate language teaching practices address, at least implicitly, the teacherlearner relationship' (Horwitz, 2000, p. 523).

The issue of teacher-learner relationship is clearly a multifaceted phenomenon whose quality is shaped and influenced by a numerous factors inside and outside of the language classroom. Moreover, since teaching and learning is a social activity, the quality of the aforementioned relationship is often strongly affected by the teacher who, as a professional, has highly significant role in the development of the supportive environment as a prerequisite for effective learning. Dinçer et al. (2013) emphasize that effective learning is strongly related to the effective teaching and indicate that an effective language teacher should possess common attributes to achieve successful language learning.

Contemporary literature offers various definitions of teacher effectiveness which include numerous determinants ranging from filed knowledge, pedagogical knowledge to affective factors. In this connection, Horwitz (2000) gives an extensive historical overview of a number of articles that have been trying to conceptualize the appropriate relationship between language learners and language teachers. However, despite the rich empirical data that up-to-date research offers, the author warns on the prevalence of research focusing solely on the investigation of teachers' perceptions, whereas learners' reflections on their classroom experiences appear sparsely.

Since the aim and the scope of this paper does not allow to go into detailed discussion on the plethora of factors affecting teacher-learner relationship and, ultimately, the quality of the learning process, our attention will be directed towards the investigation of learners' perceptions of their language teachers competences and personal characteristics and the relationship between these perceptions and learners' motivation. 


\section{LANGUAge TEACHER - DifFERENT PERSPECTIVES}

The review of contemporary literature, both theoretical and empirical, reveals that a teacher, irrespective of the subject (s)he teaches, is an important and powerful factor which may strongly affect students' level of attainment. This is even more accentuated when it comes to foreign language teacher due to the uniqueness of the learning environment. Consequently, effectiveness in the foreign language classroom may be viewed as a rather unique phenomenon because of the nature of the subject itself and, as such, cannot always be compared to the effectiveness in other disciplines. One of the first attempts to define factors unique to foreign language teaching profession was one of Hammadou and Bernhardt (1987) who identified several factors by which foreign language teacher and teaching is different from other subjects. These theoretical insights were, furthermore, widened by several prominent empirical studies such as those of Bell (2005), Borg (2006) and Park and Lee (2006) which include a wide area of issues relevant to second language acquisition and foreign language teaching. They all seem to suggest that the diversity of teachers' attributes can be categorized in two broad categories; the one referring to language teacher instructional competence and the second referring to his/her intrapersonal and interpersonal characteristics and skills. However, as pointed out in the previous paragraphs, much of the empirical research focused solely on teachers' and policy-makers' perspectives on the main 'constituents' of foreign language teacher effectiveness, while insights into students interpretations of the same are still rather scarce. The relevance of students' perceptions

This shift in methodological perspective is necessary not only for identifying students' expectations but also to determine the existence of potential discrepancies between teachers', students' and designers' perspectives on the learning process which, as a consequence, may have ineffective learning Könings et al. (2005).

Several studies, however, did try to get a grasp on the disparity in perceptions. Beaudrie et al. (2004) portrayed the teacher effectiveness from three different perspectives: teacher's, students' and the observers'. The study found significant difference between the three perspectives. The same disparity was found in Shishavan and Sadeghi's (2009) study where teachers' and students' perceptions differed to a large extent on approximately $20 \%$ of questionnaire items. The students generally gave priority to teachers' personal characteristics, such as patience, creativity and flexibility while teachers ascribed more importance to the knowledge of language, pedagogy and foreign language teaching methodology which were seen as pivotal factors that constitute effective foreign language teachers. Another comparative study conducted by Brosh (1996) asked FL students and teachers to choose three most important characteristics from the list of twenty ELT characteristics, which reflected personal, pedagogical and interactional attributes, and to rank them by their importance. Both groups perceived teachers' adequate knowledge of the target language as the first priority, followed by teachers' ability to transmit knowledge comprehensibly and to motivate students to study the language. The third priority, however, revealed significant differences between the groups: students stressed the importance of teachers' fairness and availability after class while teachers emphasized the importance of providing experience of success in students. Kadha (2009) found that both students and teachers perceive quality and preparation, planning and teacher's motivational strategies to be the most important elements of good teaching. Discrepancies n opinions were mostly related to the preferences regarding activities, where teacher gave more importance to the communicative-oriented activities while students valued traditional approach. Much of the same results were obtained by Brown (2009) in his study on effective teacher behaviors. Students and teachers demonstrated disparate beliefs on ideal teaching practices where teachers' tended to ascribe more importance to communicative approaches with frequent use of the target language and a stance on error correction. Conversely, students were more in favor of grammar-focused instruction and immediate error correction. However, they both agreed on the importance of creating good classroom atmosphere built on the proper teacher-learner relationship.

Another important dimension worth emphasizing is the affective nature of students' perceptions. Namely, recent approaches to motivation have recognized the importance of dynamic and interactive relationship between contextual factors and learning motivation. One line of the research within this framework of interest has focused on the effect instructional variables on students' attitudes and motivation and, ultimately, on the relative degree of success in language learning. As illustrated in the socio-educational model of second language acquisition (Gardner, 2010) students' attitudes towards the learning situations are formed on the basis of their experiences, i.e. perceptions of a teacher and the language learning environment. Language attitudes are shown as having a causal influence on motivation since they serve as an effective base for motivation to develop.

Several authors investigated attitudes towards the teacher as one aspect of attitudes towards the learning situation. In that sense, Mihaljević Djigunović (1998) explored the attitudes towards the teacher among elementary, secondary and university students. The author employed semantic differential scale designed to measure the following aspects of a foreign language teacher: teacher evaluation, the assessment of teacher's relationship to students, teacher's competence and teacher's inspiring quality. The effect of gender, age and grade has proven to be significant. More positive evaluation was offered by female students, participants with higher grades and university students. Students with good grades perceived their language teacher as more competent, and as having a good relationship towards students. The inspiring quality was best evaluated by elementary school participants and the worst by university population. Another study by Jakominić and Mihaljević Djigunović (2004) explored the attitudes towards the teacher among the sixth, the seventh and the eighth grade of elementary school. Generally speaking, all students perceived language teachers positively. The most favorable perceptions were found among sixth graders whereas the least positive among the eighth 
graders. The effect of the final grade have also been reported, where the most positive perceptions were given by the most successful students.

Several authors explored attitudes and motivation in foreign language learning in relation to temporal dimension. A longitudinal study conducted by Nikolov (2002) revealed the most important motivating factors for elementary school children in this study were positive attitudes toward the learning context and the teachers, intrinsically motivated activities, tasks and materials and classroom practice. The same was confirmed in EELiE - transactional, longitudinal study which explored the introduction of early language learning across seven European countries (Enever, 2011). The investigation of young learners' characteristics in relation to their achievement revealed that differences can be observed from the first grade. Students who started with more positive attitudes, higher motivation and more positive self-concept displayed higher levels of listening comprehension and oral production and these characteristics became more associated with achievement as the students got older.

\section{RESEARCH}

\section{Research aim}

The aim of the present research is to define and describe effective foreign language teacher competences as perceived by elementary school students. We also want to determine the manner in which foreign language teacher competences as perceived by students correlate with the affective variables in the learning process, respectively motivation.

Foreign language teacher competences will be defined and described from students' perspective since we are of the opinion that students' subjective perceptions of teacher have stronger influence on their achievement, than those defined by 'objective' measures.

Two hypotheses were formulated:

1. We expect a statistically relevant difference between the two types of competence perceptions, where more positive perceptions will be ascribed to a good language teacher and less positive to the actual language teacher.

2. We expect that the small difference between the two types of students' perceptions will positively correlate with higher motivation.

\section{Sample, instrument and procedure}

A sample in this study included 592 Croatian elementary school learners of English as a foreign language. In Croatian educational system, those are the children aged between 10 and 15 years, attending grades from 5th to 8th.

Students were administered three questionnaires. The first two questionnaires, Good language teacher and Actual language teacher questionnaire are comprised of the same items, but they are assessed from a different perspective. The instruments are comprised of 27 items which are distributed across three components; Intrapersonal and interpersonal characteristics and skills, Intercultural competence, and Competences related to foreign language classroom instruction. All the items are positively worded and assessed on 5-point Likert scale. The third, Motivation questionnaire is comprised of 30 items assessed on a 6-point Likert scale. The questionnaire is the adapted version of Gardner's international version of Attitude Motivation Test Battery (Gardner, 2010).

The data was collected during February and May 2016 in three urban elementary schools in Rijeka, Croatia. Detailed information on the procedure, content and the purpose of the research was given to principals, English language teachers and students involved in the research. With the aim to anticipate the guidelines outlined in Ethical codex for research with children (2003), the participants were also informed that their participation is voluntary and anonymous.

\section{RESULTS}

To determine the distribution of the obtained results, the mean and standard deviation values of the items were computed and analyzed for each instrument separately.

The analysis of Good language teacher questionnaire distribution of the data reveals that the lowest mean values are obtained for the component assessing teachers' intercultural competence $(\bar{x}=23.60, \mathrm{SD}=4.50)$, followed by the component assessing the foreign language teacher's competences related to classroom instruction $(\bar{x}=39.06, \mathrm{SD}=5.26)$ and, finally, by those assessing teacher's intrapersonal and interpersonal characteristics $(\bar{x}=52.40, \mathrm{SD}=5.09)$.

TABLE 1

COMPOSITE SCORES FOR COMPONENTS ASSESSING GOOD ENGLISH LANGUAGE TEACHER COMPETENCES AND CHARACTERISTICS

\begin{tabular}{llll}
\hline Component & & Mean & St. deviation \\
\hline Intrapersonal and interpersonal characteristics and skills & Scale sum & 52.40 & 5.09 \\
& Scale average & 4.36 & 0.42 \\
\hline Intercultural competence & Scale sum & 23.6 & 4.50 \\
& Scale average & 3.93 & 0.76 \\
\hline Competences related to foreign language classroom & Scale sum & 39.07 & 5.26 \\
instruction & Scale average & 4.34 & 0.58 \\
\hline
\end{tabular}

The results have also shown that the component assessing Intrapersonal and interpersonal characteristics and skills has the highest sample mean score $(\overline{\mathrm{x}}=4.36, \mathrm{SD}=0.42)$, followed by a slightly lower score obtained for the Competences 
related to foreign language classroom instruction $(\overline{\mathrm{x}}=4.34, \mathrm{SD}=0.58)$, and for the component assessing the teacher's Intercultural competence $(\overline{\mathrm{x}}=3.93, \mathrm{SD}=0.76)$.

The analysis of Actual language teacher questionnaire distribution of the data reveals that the lowest mean values are obtained for the component assessing teachers' intercultural competence $(\bar{x}=20.10, \mathrm{SD}=6.12)$, whereas the highest mean values were obtained for the first component, related to the teacher's intrapersonal and interpersonal characteristics and skills $(\overline{\mathrm{x}}=44.10, \mathrm{SD}=9.58)$, and for the third component whose items assessed competences related to classroom instruction $(\overline{\mathrm{x}}=33.80, \mathrm{SD}=8.45)$.

TABLE 2

COMPOSITE SCORES FOR COMPONENTS ASSESSING ACTUAL ENGLISH LANGUAGE TEACHER COMPETENCES AND CHARACTERISTICS

\begin{tabular}{llll}
\hline Component & & Mean & St. deviation \\
\hline Intrapersonal and interpersonal characteristics and skills & Scale sum & 44.10 & 9.58 \\
& Scale average & 3.67 & 0.79 \\
\hline Intercultural competence & Scale sum & 20.10 & 6.12 \\
& Scale average & 3.35 & 1.02 \\
\hline Competences related to foreign language classroom & Scale sum & 33.80 & 8.45 \\
instruction & Scale average & 3.75 & 0.93 \\
\hline
\end{tabular}

The results have shown that the component assessing Competences related to foreign language classroom instruction has the highest sample mean score $(\overline{\mathrm{x}}=3.75, \mathrm{SD}=0.93)$, followed by a slightly lower score obtained for the Intrapersonal and interpersonal characteristics and skills $(\overline{\mathrm{x}}=3.67, \mathrm{SD}=0.79)$, and for the component assessing the teacher's Intercultural competence $(\overline{\mathrm{x}}=3.35, \mathrm{SD}=1.02)$.

With the aim to examine possible statistically significant differences a paired-samples t-test was performed on three pairs:

1. Good ELT intrapersonal and interpersonal characteristics and skills (GPER) - Actual ELT intrapersonal and interpersonal characteristics and skills (APER)

2. Good ELT intercultural competence (GCUL) - Actual ELT intercultural competence (ACUL)

3. Good ELT competences related to foreign language classroom instruction (GINSTR) - Actual ELT competences related to foreign language classroom instruction (AINSTR)

TABLE 3

PAIRED-SAMPLES T-TEST RESULTS FOR THE GOOD AND ACTUAL ELT PERCEPTIONS

\begin{tabular}{|c|c|c|c|c|c|c|}
\hline \multirow[t]{2}{*}{ Pair } & \multirow[t]{2}{*}{ Component } & \multirow[t]{2}{*}{ Arithmetic mean } & \multirow[t]{2}{*}{ Standard deviation } & \multicolumn{3}{|c|}{ Paired-samples t-test } \\
\hline & & & & $\mathrm{t}$ & df. & $\mathrm{p}$ \\
\hline \multirow[t]{2}{*}{1} & GPER & 52.49 & 5.09 & 19.83 & 591 & 0.00 \\
\hline & APER & 44.10 & 9.58 & & & \\
\hline \multirow[t]{2}{*}{2} & GCUL & 23.67 & 4.59 & 13.45 & 591 & 0.00 \\
\hline & ACUL & 20.11 & 6.12 & & & \\
\hline 3 & GINSTR & 39.06 & 5.26 & 14.52 & 591 & 0.00 \\
\hline
\end{tabular}

The paired-samples t-test presented in the table above show there is a statistically significant difference between the computed mean values for all three pairs, indicating that students' perceptions of a good and the actual language teacher differ significantly.

The analysis of Motivation questionnaire distribution of the data reveals the lowest mean values were obtained for the items To be honest, I really have no desire for learning English $(\overline{\mathrm{x}}=1.62, \mathrm{SD}=1.35)$, When I leave school, I will give up the study of English because I am not interested in it $(\overline{\mathrm{x}}=1.65, \mathrm{SD}=1.36)$, and Learning English is a waste of time $(\overline{\mathrm{x}}=1.66, \mathrm{SD}=1.40)$, whereas the highest mean values were obtained for the items I wish I were fluent in English $(\overline{\mathrm{x}}=6.45, \mathrm{SD}=1.21)$, English is a very important part of the school program $(\overline{\mathrm{x}}=6.32, \mathrm{SD}=1.21)$, and I would like to learn as much English as possible $(\overline{\mathrm{x}}=6.11, \mathrm{SD}=1.41)$. The composite score values indicate the high mean values were obtained for the construct of motivation $(\bar{x}=111.54, \mathrm{SD}=50.55)$, which implies that motivation for English language learning is present among our sample. Moreover, the highest mean values obtained for the items within the questionnaire implicate the existence of positive attitudes towards learning English as a foreign language in a formal context.

After the examination and the analysis of the results obtained by each instrument separately, we used the Person correlation coefficient for the estimation of possible correlations between the variables. 
TABLE 4

\begin{tabular}{|c|c|c|c|c|c|}
\hline & Variables & DIFF-PER & DIFF-CUL & DIFF-INSTR & MOT \\
\hline & DIFF-PER & 1 & & & \\
\hline & DIFF-CUL & $.59 * *$ & 1 & & \\
\hline & DIFF-INSTR & $.66^{* *}$ & $.63 * *$ & 1 & \\
\hline & MOT & $-.30 * *$ & $-.12 * *$ & $-.18 * *$ & 1 \\
\hline & $\begin{array}{r}* * \mathrm{p}<0.01 \\
* \mathrm{p}<0.05\end{array}$ & & & & \\
\hline
\end{tabular}

As it is apparent from Table 4, motivation is found to correlate with all three variables assessing the differences in students' perceptions. Motivation is found to be in a moderate, negative and significant correlation with the differences between the perceptions of a good and the actual ELT's intrapersonal and interpersonal characteristics and skills ( $\mathrm{r}=0.30$, $\mathrm{p}<0.01$ ) whereas a weak, negative, but significant correlation was found in relation to the other two variables, that is DIFF-CUL $(r=0.11, \mathrm{p}<0.01)$ and DIFF-INSTR $(\mathrm{r}=0.17, \mathrm{p}<0.01)$.

\section{Discussion}

The findings of the current study reveal that the most important effective language teacher's characteristics are those related to his/her language teaching methodology, followed by the teacher's personal characteristics and skills and, lastly, the teacher's intercultural competence. When it comes to instructional competences, students seem to value language teacher's organizational skills, both in terms of the content that has to be covered and the nature of examination. Regarding personal characteristics, language teacher is seen as a fair person who respects his/her students, who displays enjoyment while teaching and who tries his best to transfer the content. On the other hand, leniency and sharing personal experiences are perceived to be the least desirable characteristics. Finally, with respect to intercultural competence, students perceive their teacher to be knowledgeable in the culture of English speaking countries but are of the opinion that the culture-related topics are not frequently taught in the English classes.

The finding of the current study go in line with some other studies (Mihaljević Djigunović, 1998; Jakominić \& Mihaljević Djigunović, 2004) who found that younger students tend to estimate teacher's inspirational quality and his/her competence higher than their older colleagues, which indicates the effect of age on students' perceptions of classroom variables.

Regarding personal characteristics, a possible explanation to this result may be found in children's need for emotional security, as the one of the fundamental developmental characteristic of this age group. Due to this reason, elementary school students tend to establish 'stronger' emotional attachment to the teacher, i.e. tend to perceive an emotional link to the teacher as a relevant factor within the learning context and, thus attach more importance to the teacher's personal characteristics. If this emotional connection is established, it may serve as a basis for the development of positive attitudes and, consequently, increased effort and achievement.

A more detailed inspection of the mean values indicated that there are a number of important differences between a Good and the Actual foreign language teacher perceptions. The greatest discrepancies between the expectations and reality are observed within the components assessing language teachers' personal characteristics as well as his/her instructional competences. It seems that the students are the least satisfied with the classroom working atmosphere (\#24 Makes the lesson pleasurable and relaxing for work; \#23 Holds English classes in which I can work in peace) or the lack of the discipline in class. The aforementioned is closely connected with patience - a personal characteristics which is perceived as a desirable but lacking in the everyday foreign language classroom. The quality of the learning environment also seems to be affected by the clarity in teaching along with the choices related to the activities and the materials employed during classes. It would seem that the foreign language teachers still, to the certain, extent, 'nurture' a rather traditional approach to teaching and learning which is more teacher-centered and content-centered than studentcentered.

Despite the possible dissatisfaction with the foreign language teaching methodology, elementary school foreign language students seem to display a relatively high level of motivation and positive attitudes towards learning English as a foreign language. The students, in other words, perceive the knowledge of English as an important goal which indicates that the students realize the importance, necessity and usefulness of knowing English in all areas of life.

For this reason, the students also perceive themselves as hard working learners who invest a lot of effort in their learning by working on English almost every day, writing homework regularly as well as by paying attention to the teacher's written and oral feedback.

Positive correlation between motivation and small differences between the two types of students' perceptions of their language teacher indicates that the perception of both teacher's competences related to foreign language classroom instruction and personal characteristics seem to affect students' level of motivation the most. This may be explained by the fact that the perception of the teacher as (in)competent in foreign language classroom instruction may act as a (de) motivator. In other words, students who perceive their teacher as less competent may not want to invest an effort in learning, which may, consequently, lead to low levels achievement. Conversely, students who perceive their teacher to have high levels of instructional competence will be more motivated to meet the teacher's standards and will, in turn, 
attach a certain amount of value to their own performance. Regarding personal characteristics, several studies have proven that the perception of the teacher's personal qualities may serve as the source of motivation. In this connection, Nikolov (2002) found that the most important motivating factor for elementary school children were attitudes towards the learning context, namely the teacher whereas Drakulic (2015) found that the teacher's unfavorable personality attributes were, in students' opinion, one of the main reasons for their unwillingness to participate in classroom activities. More favorable attitudes towards the learning situation also explained the variability in motivation in the study conducted by Mihaljević Djigunović (1998). The results showed that the students with higher levels of motivation invest more effort, have higher levels of desire to learn and perceive language classes as interesting, useful and not difficult. In the context of our research findings it may, therefore, be possible, that the students, on the basis of their positive perceptions of the teacher's work and personality, formed positive attitudes towards the learning situation which, consequently, affected students' level of motivation, and ultimately, the level of achievement. This causal relationship was indicated in Gardner's (2010) socio-educational model as well, but since this research is only correlational in nature, we cannot be certain about the causal aspects of these relationships.

\section{CONCLUSION}

The present study arose from the need to better understand the role of students' subjective perceptions of teacher competences in the formal school context and the nature of the relationship between students' perceptions and motivation for learning a foreign language. Returning to the hypotheses posed at the beginning of this study, it is now possible to state that both hypotheses were confirmed. The results of our study revealed significant differences in all three categories assessing English language teacher's competences, where more positive perceptions were ascribed to a good language teacher. Furthermore, the findings indicate that the level of motivation is strongly interrelated with the students' perceptions of the existence of the desirable competences of their actual language teacher.

Taken together, these results suggest that there is an association between elementary school students' motivation and their perception of their immediate language learning environment on which they form their attitudes towards the language learning situation. However, in discussing the relationship between attitudes and motivation, it is important to bear in mind the role of other factors that may affect this relationship. Nevertheless, some of the issues emerging from these findings suggest that a positive climate along with a positive relationships generally reflect the quality of the learning situation which, as such, facilitate language learning motivation and the relative degree of success.

The present study has, hopefully, accentuated that students, as active participants in pedagogical communication, represent a valuable source of information for both theory and practice. Thus, careful examination and understanding of students' perceptions of their language learning experiences should be taken into account in any further attempts for the improvement of the teaching profession as well as in the development of favorable conditions in which foreign language learning takes place.

\section{REFERENCES}

[1] Beaudrie, S., Brown, A., \& Thompson, G. (2004). Multiple Perspectives on Teacher Evaluation in the Foreign Language Classroom. Arizona Working Papers in SLAT, 11, 57-80.

[2] Bell, T.R. (2005). Behaviors and Attitudes of Effective Foreign Language Teachers: Results of a Questionnaire Study. Foreign Language Annals, 38.2, 259-270. onlinelibrary.wiley.com/doi/10.1111/j.1944-9720.2005.tb02490.x/pdf (accessed 14/11/2018).

[3] Borg, S. (2006). The Distinctive Characteristics of Foreign Language Teachers. Language Teaching Research 10.1, 3-31. http://citeseerx.ist.psu.edu/viewdoc/download?doi=10.1.1.132.6475\&rep=rep1\&type=pdf (accessed 6/10/2018).

[4] Brosh, H. (1996). Perceived Characteristics of the Effective Language Teacher. Foreign Language Annals, 29.2, 125-136. onlinelibrary.wiley.com/doi/10.1111/j.1944-9720.1996.tb02322.x/pdf (accessed 14/11/2018).

[5] Brown. (2009).Students' and Teachers' Perceptions of Effective Foreign Language Teaching: A Comparison of Ideals. Modern Language Journal, 93.1, p. 46-60,

[6] Dincer, A.,Goksu, A., Takkac, A., \& Yazici, M. (2013). Common Characteristics of an Effective English Language Teacher. International Journal of Educational Researchers, 4.3, 1-8.

[7] Drakulić, M. (2015). The 'Unforgettable' Experience of Foreign Language Anxiety. Journal of Education, Culture and Society, 1, 120-128. nowadays.home.pl/JECS/data/documents/JECS=202015=20=281=29=20120-128.pdf (accessed 6/10/2018).

[8] Enever, J. (Ed.) (2011). ELLiE. Early Language Learning in Europe. London: The British Council.

[9] Gardner, R.C. (2010). Motivation and Second Language Acquisition. The Socio-Educational Model. New York. Peter Lang.

[10] Hammadou, J. \& Bernhardt, E. (1987). On Being and Becoming a Foreign Language Teacher. Theory Into Practice, 26.4, 301306. Retrieved from https://www.jstor.org/stable/pdf/1476843.pdf (accessed 28/9/2018).

[11] Horwitz, E. (2000). Teachers and Students, Students and Teachers: An Ever-Evolving Partnership. The Modern Language Journal, 84.4, 523-535.

[12] Jakominić, N. \& Mihaljević Djigunović, J. (2004). Učenički stavovi prema nastavniku stranoga jezika, Suvremena kretanja u nastavi stranoga jezika, (Eds. Stolac, D., Ivantetić, N. i Pritchard, B.), Zagreb-Rijeka: HDPL, 187-194.

[13] Kadha, H.M. (2009). What Makes a Good English Language Teacher? 'Teachers' Perceptions and Students' Conceptions. Humanity \& Social Sciences Journal, 4.1, 1-11.

[14] Könings K.D, Brand-Gruwel S., \& van Merriënboer J.J. (2005). Towards more powerful learning environments through combining the perspectives of designers, teachers, and students. The British Journal of Educational Psychology, 75.4, 645-660. 
[15] Mihaljević, J. (1991). The Role of the Students' Perceptions of the Teacher in his Experience of the EFL Classes. Strani jezici, $10.4,236-240$.

[16] Mihaljević Djigunović, J. (1998). Uloga afektivnih faktora u učenju stranoga jezika. Zagreb. Filozofski fakultet Sveučilišta u Zagrebu.

[17] Nikolov, M. (2002). Issues in English Language Education. Bern. Peter Lang.

[18] Park, G. \& Lee, H. (2006). The Characteristics of Effective English Teachers as Perceived by High School Teachers and Students in Korea. Asia Pacific Education review, 7.2, 236-248. Retrieved from files.eric.ed.gov/fulltext/EJ752344.pdf (accessed 2/12/2018).

[19] Shishavan, H.B. \& Sadeghi, k. (2009). Characteristics of an Effective English Language Teacher as Perceived by Iranian Teachers and Learners of English. English Language Teaching, 2.4, 130-143. Retrieved from www.ccsenet.org/journal/index.php/elt/article/viewFile/4462/3803 (accessed 3/1/2019).

Morana Drakulić, PhD., is a postdoctoral researcher at the Faculty of Teacher Education, University of Rijeka, Croatia.

She received her PhD in Foreign Language Didactics from University of Slovenia, Faculty of Humanities and Social Sciences in Ljubljana in 2017. She teaches courses such as: English Language, English Language in Preschool Education, and Individual Differences in Foreign Language Acquisition. Her research interests are in the field of foreign language learning methodology, namely individual differences in foreign language learning and the relationship between students' perspectives of foreign language teacher and the affective variables within the elementary school context. Her interest is also directed towards the investiga tion of foreign language teacher competences within the specific socio-educational contexts. 